\author{
Wojciech Soliński \\ Instytut Filologii Polskiej \\ Uniwersytet Wrocławski \\ e-mail: wojciech.solinski@uwr.edu.pl \\ ORCID: 0000-0001-8244-3101
}

\title{
Z Hrabalem wśród zwierząt
}

Zwierzęta zajmują w twórczości Bohumila Hrabala tak ważne miejsce, że wprost nie sposób ich nie zauważyć1. Trzeba było jednak czasu, by jako pierwsza, na gruncie polskiej hrabalologii, zwróciła na nie uwagę Joanna Goszczyńska. Nie da się też ukryć, że bezpośredniego impulsu do skreślenia tych uwag dostarczyła mi właśnie warszawska slawistka swoim wnikliwym tekstem o „zwierzyńcu” Bohumila Hrabala². Drugi bodziec, chociaż, na swój sposób, również bezpośredni, znalazłem w tak zwanym samym życiu, czyli w ożywionej dyskusji na temat społecznego, etycznego itp. statusu polowania dzisiaj. W owej dyskusji ważne miejsce zajęła sztuka, w tym także filmowa, bo przecież roli, jaką odgrywa w niej ciągle jeszcze polsko-niemiecko-czesko-szwedzko-słowacki Pokot Agnieszki Holland i Kasi Adamik, na podstawie powieści Prowadź swój pług przez kości umartych Olgi Tokarczuk, nie można nie brać pod uwagę. Z całą pewnością esej Dariusza Czai pt. Przefarbowany świat. Mitologie polowania zamieszczony w specjalnym numerze „Kontekstów”, w całości poświęconym zależnościom pomiędzy tzw. światem ludzkim a zwierzęcym, walnie przyczynił się do powstania tych

\footnotetext{
1 By wstępnie unaocznić rozmiary problemu, zamiast tradycyjnej bibliografii umieszczam spis utworów Hrabala ze zwierzętami w tytule.

2 Por. J. Goszczyńska, Zwierzęta w krainie Hrabala, w: W poszukiwaniu przerw w zabudowie. W stulecie urodzin Bohumila Hrabala, red. nauk. J. Goszczyńska, Warszawa 2015, s. 163-175.
} 
uwag ${ }^{3}$. Hrabalowy zwierzyniec, przywołany w tymże numerze „Kontekstów" w innym tekście Dariusza Czai ${ }^{4}$, wychodzi daleko poza granice polowania, pozostając wszakże $\mathrm{w}$ obszarze problematyki zabijania zwierząt, niejako przy okazji zwraca uwagę na cały świat zwierzęcy zawarty w prozie autora Auteczka, obejmujący nie tylko jego koty czy tak zwaną zwierzynę łowną, ale także inne ssaki udomowione, takie jak np. psy, ale też zwierzęta hodowlane, jak bydło, trzodę chlewną i inne zwierzęta hodowane przez człowieka dla mięsa, mleka, wełny, skórek, jajek itp. Nie może być wątpliwości, że najżywsze, najgłębsze i najbardziej, chce się rzec, dialektycznie zapętlone są związki pisarza z kotami. Swoje miejsce, jak była o tym mowa wcześniej, ma także w prozie czeskiego pisarza dzika zwierzyna leśna, traktowana od bardzo dawna jako tzw. zwierzyna łowna. Sporo miejsca zajmują też ptaki, wśród których na pierwszy plan wlatują gołębie, te hodowane, pocztowe, ale również te żyjące dziko w przestrzeni miejskiej ${ }^{5}$. Wystarczy wspomnieć, jak ważną rolę pełnią gołębie hodowane przez zawiadowcę stacji w Pociagach pod specjalnym nadzorem. W tymże tekście rzuca się w oczy dramatyczny opis transportu bydła i owiec na rzeź, ale także okrutny, domowy sposób tuczenia gęsi praktykowany przecież do dzisiaj i to nie tylko przez żonę zawiadowcy.

O ile w Pociagach... kwestię okrutnego transportu zwierząt rzeźnych, szczególnie krów i owiec, można przypisać Niemcom, o tyle - już bez wojennego kontekstu - ów transport, i "wszystko, co odbywa się podczas uboju” zagraża życiu narratora Auteczka. To w tym utworze, opatrzonym podtytułem Ballada, gdzie między innymi znajdujemy drastyczny opis przewożenia i zabijania zwierząt rzeźnych, przeczytać możemy też dramatyczne, miejscami tragiczne, autorskie wyznanie grzechów popełnionych przez niego i ludzkość wobec naszych braci mniejszych ${ }^{6}$.

3 Por. D. Czaja, Przefarbowany świat. Mitologie polowania, „Konteksty. Polska Sztuka Ludowa” 2009, nr 4, s. 110-125.

4 Por. D. Czaja, Filozofowie i zwierzęta. Poeci i zwierzęta. Wypisy z ksiag użytecznych, „Konteksty” 2009, nr 4, s. 10-26.

5 Szczególne miejsce zajmują w twórczości Hrabala metaforycznie potraktowane Skowronki na uwięzi [Skřivánci na niti]. Książka, która - ukończona w roku 1958 - ujrzała światło druku cztery lata później, a jej długie trwanie zapewnił zrealizowany na jej podstawie film pod tym samym tytułem. Tytułowe skowronki to więźniarki polityczne wykorzystywane przez władze komunistyczne do niewolniczej pracy na złomowisku huty $\mathrm{w}$ Kladnie. $\mathrm{O}$, napisanych przez cenzurę, losach tekstu i filmu, opowiada autor w tekście zatytułowanym Prekrasný osud skřivanku் [Przedziwny los skowronków], w: tegoż, Sebrané spisy Bohumila Hrabala [dalej jako SsBH], t. 15, s. 244-246. Hrabal nie mógł wówczas wiedzieć, że film będzie dwudziestoletnim „półkownikiem”.

6 Por. B. Hrabal, Autíčko. Balada, w: tegoż, Sebrané spisy Bohumila Hrabala, t. 12, s. 102-103. Polski przekład Auteczko. Ballada, przeł. J. Pacześniak, Kraków 2003, s. 14-15. 
W tomie Taka piękna żałoba napotykamy tekst zatytułowany Kiedy umiera gospodarz, nawet bydlatka płacza, w którym bodaj najpełniej wyrażony jest uwikłany w mitologię stosunek Hrabala do powiązań wzajemnych między światem ludzkim i światem zwierzęcym. Dziecięcy narrator opowiada o zaiste symbiotycznym związku pewnego owczarza, zwanego Owczym Królem, ze stadem owiec mieszkających wraz z nim w zapuszczonym domostwie. Jeszcze przed pogrzebem Owczego Króla, w którym uczestniczyły trzy osoby: dziecięcy narrator, brat Króla i grabarz, zarżnięto wszystkie owce:

A każda owieczka, zobaczywszy rzeźników, sama podbiegała, kładli ją na grzbiecie między [...] dwie deski na koźle do rżnięcia drewna, owieczka sama wyciągała szyję - i błyskał nóż, i tryskała krew. Za ostatnią owcą wybiegło jagniątko. Kiedy owcę położono na grzbiecie, to jagnię wspięło się i zaczęło ssać. Ale rzeźnicy jednym pociągnięciem ostrego noża poderżnęli gardło także i tej ostatniej owcy. A jagnię nadal ssało. Jeden z rzeźników pochylił się i chciał zarżnąć również i to jagniątko, ale drugi rzeźnik powiedział:

- To sobie zostawiamy, to baranek, weźmiemy go ze sobą ${ }^{7}$.

Kiedy, w jakiś czas później, narrator ma okazję zapytać o dalsze losy ocalonego baranka, dowiaduje się od jednego z rzeźników, że w ubojni puszczają go z dzwonkiem:

i on chodzi od jednego kojca do drugiego, [...] a owieczki, słysząc wesołe brzęczenie, podnoszą się i idą za nim, a on nam je przyprowadza wprost pod nóż. I za każdym razem dostaje kromkę chleba posypanego solą. On to bardzo lubi.

I to jest nagroda za jego pracę. Rozumiesz chłopcze?

- Nie rozumiem, proszę pana - powiedziałem. - Ale jak dorosnę, to na pewno zrozumiem ${ }^{8}$.

Jeszcze raz wierny czytelnik Hrabala ma okazję obserwować ucieleśnianie się pisarskiego credo autora, który opisuje otaczającą go bryłę świata $\mathrm{w}$ poetyce swoistego totalnego realizmu dominującego artystyczną przestrzeń jego dzieł, zawsze bez złudzeń, bez fałszywego zdziwienia, i - co może ważniejsze - bez prób ruszania jej z posad.

Zupełnie inaczej - lirycznie i nadrealistycznie zarazem - prezentują się mewy we wczesnym wierszu Hrabala i późniejszej prozie poetyckiej ${ }^{9}$. A gołę-

7 B. Hrabal Když umře hospodar, pláče i dobytek, w: tegoż, Sebrané spisy Bohumila Hrabala, t. 10, s. 104. Polski przekład Kiedy umiera gospodarz, nawet bydlatka płacza, przeł. A. Czcibor-Piotrowski, w: tegoż, Taka piękna żałoba, s. 135.

8 Tamże, s. 133-137.

9 Por. B. Hrabal, Rackové [Meww], w: tegoż, Sebrané spisy Bohumila Hrabala, t. 1, s. 9. Proza poetycka w zbiorze Etudy [Etiudy], w: tegoż, Sebrané spisy Bohumila Hrabala, t. 5, s. 388. Polski przekład, B. Hrabal, Mewy. Etiudy, przeł. M. Bogdańska, „Literatura na Świecie” 1971, nr 5. 
bie miejskie odgrywają $\mathrm{w}$ jego prozie szczególną rolę, nierozerwalnie wiążąc się $\mathrm{w}$ niej $\mathrm{z}$ problemem wypadania czy też wyskakiwania $\mathrm{z}$ okna ${ }^{10}$. Pisałem już o tym, więc teraz ograniczę się tylko do przypomnienia, że w Zaczarowanym flecie i w Liście do Kwiecieńki, w prozie zatytułowanej Publiczne samobójstwo, motyw gołębi i „autodefenestracji” są ściśle ze sobą powiązane. Mamy tam też do czynienia $\mathrm{z}$ dramatycznym głosem $\mathrm{w}$ dyskusji na temat odchodzenia w przeszłość tak zwanego czeskiego gołębiego charakteru, polegającego między innymi na dokarmianiu gołębi, fotografowaniu się z nimi, na manifestacyjnej wręcz obecności, na placach zabaw czy w parkach, chorągwi z białą gołębicą Picassa. Nadawca listu stwierdza z goryczą, że teraz mieszka w mieście:

gdzie już od z górą dwóch lat rozpoczęto walkę z gołąbkami, gołąbków jest coraz mniej i mniej, znikają... tu i ówdzie stąpa jeden albo stadko, dziobią, co tam im kto rzuci... lecz uwaga: według gazet i czasopism, to jest już wzbronione, bo gołąbek zagraża ludzkiemu zdrowiu, jest niebezpieczny... i karmienie gołębi jest niepożądane, niemal karalne...Widziałem już nawet, że ludzie odrzucają kopniakami nazbyt ufne gołąbki, kopią je, i są ludzie, którzy krzyczą i grożą złożeniem skargi, kiedy widzą jak ktoś karmi ten masz gołębi charakter, te piękne niewinne gołąbeczki... ${ }^{11}$.

Powyższą uwagę można traktować jako przejaw takiego polowania, które zamienia się $\mathrm{w}$ dobrze zaplanowaną wojnę $\mathrm{z}$ "plagą", wypowiedzianą przez tych samych, którzy ją wywołali, teraz występujących w roli myśliwych. Wszyscy czytelnicy prozy Bohumila Hrabala pamiętają też zapewne epizod z dzikiem „upolowanym” w klasie szkolnej; z łosiem z Polski, który poturbował kilka samochodów zanim „został pozyskany” przez członków kerskiego koła łowieckiego, czy z meklemburską krową, która postanowiła pohulać na wolności, by ostatecznie dokonać żywota podobnie jak wcześniej wspomniany dzik czy swawolny „polski łoś”. Inna krowa, o kwietnym imieniu, została bohaterką bajki dla dzieci z morałem daleko wykraczającym poza ramy tekstu ad usum Delphini. W czytelniczej pamięci pozostaje też swoiste drogowe polowanie, jakie urządził sobie pewien kierowca, który w ostatnim zdaniu opowiadania Chrzciny 1947, okazuje się być księdzem ${ }^{12}$. We wcze-

${ }^{10}$ W tym kontekście trzeba pamiętać o okolicznościach śmierci Hrabala, który albo wypadł ze szpitalnego okna karmiąc gołębie, albo też się z niego rzucił.

11 B. Hrabal,Verejná sebevražda, w: tegoż, Sebrané spisy Bohumila Hrabala, t. 13, s. 34. Polski przekład: B. Hrabal, Publiczne samobójstwo, przeł. A. Czcibor-Piotrowski, w: tegoż, Listy do Kwiecieńki, Warszawa 2004, s. 39.

12 Opowiadanie Chrzciny 1947 dostępne jest w dwóch polskich przekładach, w trzech edycjach: B. Hrabal, Chrzciny 1947, przeł. E. Witwicka, w: tegoż, Aferzyści, Katowice 1983, s. 56; 
śniejszej wersji tego tekstu pt. Chrzciny ${ }^{13}$, czytelnik wie o tym od samego początku. Przy tej okazji warto jeszcze raz zaznaczyć, że określenie łowy czy polowanie nie będzie tu traktowane rygorystycznie, chociaż uwag na temat tzw. etosu polowania, zwyczajów łowieckich nie da się uniknąć, bo też jest polowanie, podobnie jak wędkowanie, masowo obecne $\mathrm{w}$ tradycji kulturalnej Czechów, w tym także w czeskiej tradycji literackiej ${ }^{14}$. Nawiązując do tego, co już tu powiedziano, i antycypując to, co nastąpi, trzeba nadmienić, że Hrabal poczyna sobie z ową tradycją nader swobodnie, już to dworując z niej, już to piętnując to, co nazwę tutaj skutkami ubocznymi, a co kładzie się na tej tradycji głębokim, i wciąż się pogłębiającym, cieniem.

Biorąc pod uwagę liczne, epizodyczne wzmianki na temat świata zwierzęcego, rozsiane po całej prozie Hrabala, trzeba oświadczyć, że stosunek pisarza do owego świata należy rozpatrywać na osi od ich uświęconej tradycją antropocentrycznej wizji do współczesnego zwierzęcego punktu widzenia ${ }^{15}$. A wszystko miało zacząć się w czasach ludzko-zwierzęcej wspólnoty, określanej $\mathrm{w}$ pracach $\mathrm{z}$ zakresu animal studies mianem mutualizmu, która trwała przez dziesiątki tysięcy lat. Wówczas ludzie wchodzili w bardzo głębokie relacje z przyrodą, prowadzące do wspomnianej antropocentrycznej wizji świata zwierzęcego. Nieco upraszczając można uznać, że w prozie czeskiego pisarza na jednym biegunie byłby to „apetyczny” (?!) sposób opisu świniobicia przez bohaterkę-narratorkę Postrzyżyn, na drugim dramatyczny monolog konającego jelonka Lesana z Najpiękniejszych oczu. Czytelnik ma też możliwość prześledzenia swoistego łańcucha pokarmowego od najróżniejszych sposobów uśmiercania zwierząt dzikich czy hodowlanych, poprzez ich sprawianie, przyrządzanie, aż do momentu ich spożywania, ukazywanego nierzadko w sposób, który budzić może, i budzi, obrzydzenie, jak na przykład opis „wyżerki” z okazji świniobicia (po czesku: zabijačka),

B. Hrabal, Chrzciny 1947, przeł. A. Czcibor-Piotrowski, w: tegoż, Legenda o pięknej Julci. I inne opowiadania, Kraków, s. 17; B. Hrabal, Chrzciny 1947, przeł. E. Witwicka, w: tegoż, Perełka na dnie. Rozmowy, Warszawa 2012, s. 180.

13 Por. B. Hrabal, Křtiny, w: tegoż, Sebrané spisy Bohumila Hrabala, t. 3, s. 163. Ta wcześniejsza wersja nie była, o ile mi wiadomo, tłumaczona na język polski.

14 Problematykę polowania, hodowli ryb, a szczególnie uroki wędkowania, porusza w swoich bardzo często dramatycznych opowiadaniach czeski pisarz żydowskiego pochodzenia, Ota Pavel (1930-1973). Por. O. Pavel, Śmierć pięknych saren. Jak spotkałem się z rybami, przeł. A. Czcibor-Piotrowski, Warszawa 2015.

$15 \mathrm{Z}$ owej antropocentrycznej wizji historii - postulowanej przez francuskiego badacza - nie udaje się Hrabalowi, mimo widocznych wysiłków, uwolnić, by przejść za stronę zwierząt, przyjąć bez wahania ich „punkt widzenia”. Por. É. Baratay, Zwierzęcy punkt widzenia. Inna wersja historii, przeł. P. Tarasewicz, Gdańsk 2014, s. 10 i 16. 
znajdujący się w napisanym w 1952 roku opowiadaniu opatrzonym przez autora gorzko-prześmiewczym tytułem Sympozjon ${ }^{16}$.

W mocy pozostaje jednak uwaga Joanny Goszczyńskiej, że kluczowym tekstem, pozwalającym głęboko zajrzeć w koci świat Hrabala pozostaje $A u$ teczko ${ }^{17}$. Zakres tej konstatacji należy rozszerzyć na całą Hrabalową Faunę. Podobnie oczywista wydaje się obserwacja, że trudno od zmarłego w 1997 roku czeskiego pisarza wymagać dzisiaj coraz powszechniejszej wrażliwości na zmiany dokonujące się $\mathrm{w}$ sferze stosunku ludzkości do zwierząt, w której (na szczęście?!) zaczyna dominować skłonność do obdarzania naszych „braci mniejszych" prawami.

Polowanie, w tym także to, co można określić mianem „etosu polowania” czy „kodeksu honorowego myśliwych”, wiąże się w prozie autora Auteczka z obszarem kerskich lasów, w których znajdowała się jego "chata”. W ten sposób także problematyka szeroko rozumianego polowania wiąże się z „kwestią kocią", której kumulacją jest właśnie swoista spowiedź i pokuta za krwawe ograniczenie populacji zaprzyjaźnionych kotów. Cechą szczególną tego tekstu jest stan dramatycznego napięcia między rzeczywistą przecież, nie zaś tylko deklarowaną, miłością do tych zwierząt, a koniecznością utrzymania ich rozmnażania się $\mathrm{w}$ jakichś granicach akceptowalnych $\mathrm{z}$ uwagi na ograniczone możliwości wyżywienia i zapewnienia opieki tym udomowionym przez człowieka stworzeniom (w tym także tzw. planowy odstrzał dziko żyjących psów i kotów czy wyłapywanie bezpańskich kotów, jako zwierząt laboratoryjnych, przez hyclów, zwanych też wędrownymi katami). Podobnie rzecz się ma z tzw. etosem myśliwskim, który od pewnego czasu funduje się na przekonaniu, że pogłowie dzikiej zwierzyny leśnej należy utrzymywać w stanie bezwzględnej równowagi ze względu np. na szkody wyrządzane przez nią w uprawach rolnych. Zauważonym przez Hrabala, chce się rzec, dialektycznym cieniem na wspomnianym wyżej etosie myśliwskim kładzie się wynagradzanie „myśliwych” za każdego odstrzelonego bezpańskiego psa czy kota.

Szeroką panoramę tych specyficznych Hrabalowych polowań otwiera opowiadanie Chrzciny 1947, w którym - oczyma autostopowicza - obserwujemy poczynania kierowcy wyraźnie polującego na przebiegające przez drogę zwierzęta leśne. Kiedy wreszcie udaje mu się potrącić sarnę, którą okrutnie dobija, a następnie stara się zatrzeć wszelkie ślady tego morder-

16 Por. B. Hrabal, Symposion, w: tegoż, Sebrané spisy Bohumila Hrabala, t. 3, s. 196-199. Polski przekład: B. Hrabal, Sympozjon, w: tegoż, Rozpirzony bęben. Opowieści wybrane, wybór i przekład J. Waczków, Warszawa 2005, s. 97-102.

17 Por. B. Hrabal Autíčko. Balada, s. 95-163. 
stwa z premedytacją, trochę zdumiony, chociaż asystujący w nim autostopowicz, dowiaduje się, że „myśliwym kierowcą” jest ksiądz jadący, by udzielić chrztu.

Nieco inny, w dużym stopniu groteskowy, obraz polowania znajdzie czytelnik $\mathrm{w}$ opowiadaniu pt. Uczta ${ }^{18}$, w którym wytropiony i raniony, na polu koszonej pastewnej kukurydzy, dzik ścigany przy użyciu zarekwirowanego roweru, pchanego przez dwóch członków koła łowieckiego, ponieważ zasiadający na nim strzelec nie nauczył się jeździć, zostaje wreszcie "pozyskany” w klasie szkolnej, na oczach zdumionych uczniów i rezolutnej - choć trochę przestraszonej - nauczycielki, objaśniającej właśnie prawidłowy rozkład tuszy wieprzowej. Przy okazji okazuje się, że ścigając odyńca myśliwi przekroczyli granice ich rewiru, w czego rezultacie mają prawo do myśliwskich trofeów, ale nie do tuszy. Narastający konflikt między zwaśnionymi łowcami łagodzi na jakiś czas nauczycielka, proponując wspólną konsumpcję na terenie neutralnej restauracji, a także ustalając menu, mające zadowolić zwaśnionych biesiadników. Podczas uczty spór rozpala się na nowo, i wtedy $\mathrm{w}$ samą porę pojawia się przedstawiciel władzy ludowej w osobie komendanta posterunku, który definitywnie, wykorzystując także autoironię i stan upojenia alkoholowego myśliwych, rozstrzyga spór w sposób, który nauczycielka w ramach lekcji wychowania obywatelskiego, podaje jako przykład pokojowego rozstrzygnięcia tysiącletniej kwestii czeskiej ${ }^{19}$. Polski czytelnik może mieć tu skojarzenia typu dzik a sprawa polska.

To tyleż straszne, co śmieszne polowanie, znakomicie pokazane przez Jiř́ho Menzla w adaptacji filmowej tego opowiadania, w całej swej groteskowości odbija się jak w lustrze w poniżej cytowanym fragmencie ważnej pracy klasyka animal studies:

Aby uzasadnić krzywdzenie zwierząt, ludzie wcale nie muszą tworzyć deprecjonujących je stereotypów. Retoryka współczesnego sportu myśliwskiego często $\mathrm{z}$ prawdziwym uczuciem przedstawia je $\mathrm{w}$ pełnych pochwały lub podziwu słowach. Wynosi je do roli godnego przeciwnika w pasjonującej grze życia i śmierci; przeciwnika, którego nic tak nie cieszy, jak wykazanie własnej siły, szybkości i sprytu we współzawodnictwie z dobrze uzbrojonym człowiekiem. Przypisując w ten sposób wyimaginowaną siłę, myśliwi mogą z czystym sumieniem zabijać, potwierdzając zarazem własną wyższość nad pokonaną zdobyczą ${ }^{20}$.

18 B. Hrabal, Hostina, w: tegoż, Sebrané spisy Bohumila Hrabala, t. 8, s. 146-159. Polski przekład: B. Hrabal, Uczta, przeł. J. Stachowski, w: tegoż, Święto przebiśniegu, Warszawa 2008, s. 191-204.

19 Aluzja do krwawo rozstrzyganych czeskich sporów dynastycznych.

20 J. Serpell, W towarzystwie zwierząt. Analiza związków ludzie-zwierzęta, przeł. A. Alichniewicz, A. Szczęsna, Warszawa 1999, s. 223. 
We wspomnianym już wcześniej opowiadaniu Wściekła krowa mamy do czynienia z podobnie niezwykłymi polowaniami na zdziczałą meklemburską krowę, czyniącą szkody w uprawach rolnych, i na - rzekomo zabłąkanego z Polski - łosia, który spowodował kilka wypadków drogowych, taranując samochody. Także w tym utworze zostają „pozyskane” z uwagi na szkody czynione $\mathrm{w}$ uprawach rolnych. Ale oba te pozornie groteskowe polowania służą jako pretekst do wskazania na genezę tego tekstu, a także do wyartykułowania w konkluzji ustami narratora, komendanta posterunku milicji, dramatycznego apelu o humanitarne traktowanie najlepszych przyjaciół człowieka:

Tak więc widzicie, co się w naszej okolicy może wydarzyć przez to, że ludzie na leśnym odcinku szosy wyrzucają psiaki, co się może zdarzyć, gdy ja w imię sprawy strzelam w oborze do pieska, a przy tym urywa się i bzikuje drogocenna meklemburska krowa za trzydzieści tysięcy, która tu teraz leży w charakterze kupy mięsa do utylizacji albo do ogrodu zoologicznego. Dlatego powiadam: nie wyrzucajcie piesków z samochodów ${ }^{21}$.

Na marginesie tych uwag przyjdzie też zwrócić uwagę na, pozornie w tym kontekście incydentalny, epizod w aktywności pisarskiej Hrabala, a mianowicie na zajęcie się przez niego gatunkami literackimi przypisanymi tradycją odbiorcy dziecięcemu. Przypomnijmy, Hrabal nie miał dzieci, sam - jako tzw. dziecko nieślubne ${ }^{22}$ - został usynowiony i nosił nazwisko swego ojczyma, który całkowicie zastąpił mu biologicznego ojca. W świetle tej obserwacji dwa teksty można uznać za skierowane do odbiorcy dziecięcego. Inna krowa, oprócz wspomnianej wyżej zbuntowanej meklemburskiej jałowicy, o kwietnym imieniu Kopretina/Złocieńka, została bohaterką bajki dla dzieci z morałem daleko wykraczającym poza ramy tekstu ad usum Delphini. Ta, dziejąca się w socjalistycznej spółdzielni rolniczej, historia krowy, która ocieliła się potajemnie w leśnym ustroniu, by - jak domyśla się gminny pastuch - obronić, z pomocą licznych "ciotek", noszących jak ona kwietne imiona, swojego synka Doubka/Dąbka przed oddzieleniem od matki i zimnym chowem z przeznaczeniem na cielęcinę - zostaje przez tegoż pastucha

21 B. Hrabal, Zdivočelá kráva, w: tegoż, Sebrané spisy Bohumila Hrabala, t. 8, s. 42-43. Polski przekład: Wściekła krowa, w: B. Hrabal, Święto przebiśniegu, przeł. J. Stachowski, Izabelin 2008, s. 52. Por. też: B. Hrabal, Wściekła krowa, przeł. J. Waczków, w: tegoż, Legenda o pięknej Julci i inne opowiadania, Kraków 1990, s. 100.

22 Po czesku o dziecku nieślubnym zwykło się mawiać jako o „lewoboczku”, czyli z nieprawego łoża. Por. J. Baluch, "Lewoboczek” $i$ "Pabitele”. Felieton filologiczny z dwoma podtytułami..., „Nurt" 1969, nr 8, s. 40-42. 
zapewniona, że jej sekret nie będzie ujawniony. I nie jest ważne, że doświadczona dojarka nie dostrzega krowiej ciąży; i nie jest ważne, że tajemnicy nie da się na dłuższą metę utrzymać23. Bajki nie kończy zwrot typu: żyli długo i szczęśliwie; kończy ją swego rodzaju utopijne pocieszenie/consolazione ${ }^{24}$ : brutalnego biegu rzeczy tego świata nie da się zatrzymać, ale można go na pewien czas opóźnić.

Najpiękniejsze oczy to całkowicie zantropomorfizowany, przejmujący monolog wewnętrzny (?!) małego jelonka, tęskniącego za „pozyskanymi” w rezultacie polowania matką i braciszkiem (wcześniej okulawionym przez kombajn zbożowy), który musi sobie radzić sam w otaczającym go wrogim środowisku; opowiadającego o powolnym pokonywaniu bariery strachu przed ludźmi; o przyjaźni z synkiem leśniczego i jego matką, którzy zastępują mu jego własną matkę i braciszka; kończący się dramatycznym finałem, w którym koziołek nieoczekiwanie staje się dla swojego ludzkiego braciszka swego rodzaju "chłopcem do bicia" i zostaje "pozyskany" podczas polowania, stając się główną nagrodą $w$ loterii fantowej w czasie zabawy w dniu świętego Szczepana. Konając widzi, jak pochylają się nad nim: „te najpiękniejsze w świecie oczy, jakie miała moja mamusia, a teraz także moja druga mamusia, oczy, w których mieścił się cały świat, czyli i ja... Mamusiu, mamusiu!"”25.

Ten przejmujący w swej wymowie tekst wikła problematykę stosunków między światem zwierzęcym i ludzkim, w narastającą kwestię coraz dalej idącej ingerencji człowieka w przestrzeń życiową dziko żyjących zwierząt, $\mathrm{w}$ rezultacie, między innymi, „czynienia sobie ziemi poddaną". W prozie Hrabala problemy z tym związane zajmują miejsce niepoślednie. Wystarczy przypomnieć, wspomniane tu już wcześniej, prześladowane w przestrzeni miejskiej gołębie, za niszczenie czy wręcz „znieważanie” zabytków architektury czy pomników, wcześniej traktowane jako swego rodzaju atrakcja turystyczna; dokarmiane po to, by np. stanowić malownicze tło do pamiątkowych fotografii. $\mathrm{W}$ rezultacie ich populacja wzrosła nadmiernie i stanowi zagrożenie ze względu na możliwość roznoszenia bakterii szkodliwych dla człowieka.

23 Por. B. Hrabal, Kopretina, w: tegoż, Sebrané spisy Bohumila Hrabala, t. 4, s. 368-372. Polski przekład: B. Hrabal, Złocieńka, przeł. W. Soliński, Warszawa 2014.

24 Termin użyty przez Umberta Eco w eseju Eugène Sue: il socialismo e la consolazione, zamieszczonym w tomie Il superuomo di massa. Retorica e ideologia nel romanzo popolare, Milano 1999. Por. polski przekład U. Eco, Eugeniusz Sue: socjalizm i pocieszenie, przeł. J. Ugniewska, w: tegoż, Superman w literaturze masowej. Powieść popularna między retoryka a ideologia, Kraków 2007.

25 B. Hrabal, Nejkrásnější oči, w: tegoż, Sebrané spisy Bohumila Hrabala, t. 8, s. 63-77. Tamże wariant tego tekstu: Maminčiny oči [Oczy mamusi], s. 211-223. Polski przekład: B. Hrabal, Najpiękniejsze oczy, przeł. J. Stachowski, w: tegoż, Święto przebiśniegu, Warszawa 2008, s. 97. 
W ten sposób „zwierzęca proza” Hrabala wpisuje się w niezwykle istotną dziś kwestię regulacji populacji zwierzyny leśnej i nie tylko. Obserwujący ten problem badacze spod znaku animal studies na ogół nie mają złudzeń, że wystarczy przestać „potrząsać przyrodą” (np. nie dokarmiać z jednej strony, i nie zabijać z drugiej), czyli „pozwolić, by zwierzęta rządziły się swoimi prawami w przekonaniu, że w ten sposób wszystko wróci do naturalnego stanu". Takie myślenie Dariusz Czaja określa mianem życzeniowego:

Nie kwestionując zasadniczej tezy o negatywnych skutkach ludzkiej ingerencji $\mathrm{w}$ przyrodę, można wątpić, czy rezygnacja ludzi z polowań na masową skalę W sposób automatyczny zrodzi dobrostan, który stanie się udziałem wszystkich ${ }^{26}$.

Być może pewne uwagi i obserwacje Hrabala dotyczące zwierząt nie znajdą uznania $\mathrm{w}$ oczach niektórych przedstawicieli animal studies. Pamiętamy jednak o wspomnianej już wyżej, konsekwentnie przestrzeganej przez czeskiego autora poetyki opisu otaczającej go rzeczywistości jako opresyjnej, konserwatywnej, bez intencji jej zmieniania, co zresztą powodowało częste oskarżanie go o obyczajowy tradycjonalizm czy polityczny konformizm, a nawet o tchórzostwo. Podobnie jak w oczach feministek niektóre uwagi dotyczące seksistowskiego traktowania kobiet - nie tylko - w tradycyjnej małomiasteczkowej społeczności ${ }^{27}$.

Zbliżając się ku zakończeniu warto zauważyć, że Bohumil Hrabal bodaj już jako "okazjonalny bajkopisarz" wydaje się najmocniej, wręcz dramatycznie - a zawsze na swój sposób - antycypować problematykę żywiołowo rozwijających się dziś na uniwersytetach całego świata animal studies. Jego wielostronny ogląd problematyki polowania, w świetle współczesnej nad nim refleksji, rozciąga się $\mathrm{w}$ przestrzeni od rozumienia tzw. sztuki łowieckiej jako szlachetnego hobby i skutecznej formy ochrony przyrody, po mordowanie niegroźnej, wręcz niewinnej leśnej zwierzyny przez żądnych tzw. myśliwskich trofeów ludzkich samców traktujących ten krwawy proceder jako swoiste hobby, ze znakiem przeciwnym do tego, wspomnianego wyżej, szlachetnego.

\footnotetext{
26 D. Czaja, Przefarbowany świat, s. 124.

27 Na przykład scena wymierzania kary chłosty przy pomocy pompki rowerowej przez męża narratorki-bohaterki Postrzyżyn, która ośmieliła się ściąć przepiękne długie włosy bez jego zgody, za który to epizod autor został zaatakowany parasolką przez amerykańską feministkę.
} 
Charakterystyczną cechą całej „zwierzęcej prozy” Hrabala jest jego brak złudzeń co do tak zwanej idealizacji natury, może najbardziej widoczny wtedy, kiedy w Auteczku obserwuje okrutną zabawę jego ukochanych kotek ze skrajnie przerażonym zajączkiem, który - na jego przerażonych oczach - umiera ze strachu. I puentuje to wydarzenie, zwracając się do żony: „To sama natura, powiedziałem, ale nie byłem pewien, czy mam rację" 28 , bo obserwując tę scenę zdaje sobie sprawę, że okrucieństwo świata natury nie jest iluzją; że wzajemne pożeranie się, polowanie na inne osobniki, eliminacja słabszych, walka między poszczególnymi gatunkami to codzienność w tym świecie. Sam obserwator daleki jest od przeciwstawiania „niewinnej natury” "złej kulturze”, bo - jako miotający się między nimi współwinny - doskonale rozumie, że "okrucieństwo natury różni się nieco od ludzkich praktyk: nie ma bowiem żadnych konotacji etycznych, dzieje się niejako "poza dobrem i złem». Tylko ludzkie zabijanie podpada pod kwalifikacje etyczne" 29 .

Sytuację, w jakiej znajduje się bohater-narrator, można, idąc za myślą cytowanego tu już Jamesa Serpella, zamknąć konstatacją, że bodaj zawsze zabijaniu zwierząt przez człowieka towarzyszyła refleksja etyczna: „Ukryte poczucie winy i potrzeba pokuty za zabicie są bardzo częste, jeśli nie powszechne, u ludów łowieckich, choć mogą różnie się wyrażać" ${ }^{30}$.

W opinii większości zwolenników polowania współczesne myślistwo ma być całkowicie pozbawione tego archaicznego komponentu, bo przecież np. zwierzęca krew to tylko farba, a zabijanie zwierząt to ich (kontrolowane) pozyskiwanie; bo przecież: „,sztuka łowiecka to nie tylko wzbogacające i pożyteczne hobby, ale też potrzebna i wielce skuteczna forma ochrony przyrody" ${ }^{31}$. Tymczasem w opinii jego przeciwników, takie, i inne jeszcze, mitologiczne wmówienia, mają zastąpić refleksję moralną.

W całej prozie zwierzęcej Hrabala - bo nie tylko w mniej lub bardziej gorzko-groteskowych tekstach na temat polowania - charakterystyczne jest miotanie się jej narratorów i bohaterów pomiędzy poczuciem winy wobec braci mniejszych, a wyrażonym już tutaj przekonaniem, że powrót do stanu, kiedy zwierzęta rządziły się swoimi prawami, który określić by można mianem naturalnego, to klasyczny przykład myślenia życzeniowego.

\footnotetext{
28 Por. B. Hrabal, Autíčko. Ballada, s. 136.

29 D. Czaja, Przefarbowany świat, s. 125.

30 J. Serpell, W towarzystwie zwierząt, s. 199.

31 D. Czaja, Przefarbowany świat, s. 110.
} 


\section{Zwierzęta w tytułach utworów Bohumila Hrabala (w kolejnych tomach Sebrané spisy Bohumila Hrabala i w przekładach na język polski) ${ }^{32}$ :}

1. Rackové [Meww]. Najpierw jako wiersz w zbiorze Dni a nocy, SsBH, t. 1, Praha 1991, s. 9, następnie jako proza poetycka w zbiorze Etudy [Etiudy], SsBH, t. 5, Praha 1994, s. 388. Polski przekład, Mewy. Etiudy, przeł. M. Bogdańska, „Literatura na Świecie” 1971, nr 5.

2. Dnes zapadalo slunce krvavé jak rajka... [Dziś słonce zachodziło krwawo jak rajski ptak], w zbiorze Obrázky bez rámu [Obrazki bez ram], SsBH, t. 5, s. 429.

3. Štědrý den je kaprů Velký pátek [Wigilia Bożego Narodzenia to dla karpi Wielki Piątek], w zbiorze Obrázky bez rámu [Obrazki bez ram], SsBH, t. 5, s. 432.

4. Hostinec u bernardyna, w zbiorze Slavnosti sněženek, SsBH, t. 8, Praha 1993, s. 9. Polski przekład Gospoda "Pod Bernardynem" 33 , w: B. Hrabal, Święto przebiśniegu, przeł. J. Stachowski, Izabelin 2008, s. 7.

5. Zdivočelá kráva, w zbiorze Slavnosti sněženek, SsBH, t. 8, s. 38. Polski przekład: Wściekła krowa, w: B. Hrabal, Święto przebiśniegu, przeł. J. Stachowski, Izabelin 2008, s. 46.

6. Králíčci v kř́ldle, w zbiorze Slavnosti sněženek, SsBH, t. 8, s. 44. Polski przekład: Fortepian i króliki, w: B. Hrabal, Święto przebiśniegu, przeł. J. Stachowski, Izabelin 2008, s. 53.

7. Lucinka a Pavlina, w zbiorze Slavnosti sněženek, SsBH, t. 8, s. 135. Polski przekład: Koty i ludzie, w: B. Hrabal, Święto przebiśniegu, przeł. J. Stachowski, Izabelin 2008, s. 53.

8. Myš ukradla dítěti cumel, w zbiorze Krasosmutnění, SsBH, t. 10, Praha 1994, s. 75. Polski przekład: Mysz ukradła dziecku smoczek, przeł. A. Czcibor-Piotrowski, w: B. Hrabal, Taka piękna żałoba, Izabelin 1997, s. 95.

9. Ovč̌ hubičky w zbiorze Krasosmutnění, SsBH, t. 10, s. 94. Polski przekład: Owcze pyszczki, przeł. A. Czcibor-Piotrowski, w: B. Hrabal, Taka piękna żałoba, Izabelin 1997, s. 94.

\footnotetext{
32 Nie uwzględniam tu tytułów, w których zwierzęta występują jako nazwy restauracji, hoteli itp., np.: Restaurace U Zlatého Tygra [Pod Złotym Tygrysem], U Modre Štiky [Pod Modrym Szczupakiem], Hovor u Tygra [Rozmowa pod Tygrysem], Bílý Koníček [Biały konik - lokal w Greenwich Village w Nowym Jorku].

33 Polski tytuł w tej edycji jest błędny, sugerujący, że to nazwa gospody, która nosi nazwę Hájenka [Gajówka], a tytułowy bernardyn jest jej stróżem i maskotką. Jan Stachowski tłumaczy tę nazwę jako Leśna. W reedycji tego samego przekładu, w Bibliotece Gazety Wyborczej, Warszawa 2011, tytuł zapisano już w duchu tekstu oryginalnego, jako: Gospoda pod bernardynem.
} 
10. Když umře hospodar, pláče i dobytek, w zbiorze Krasosmutnění, SsBH, t. 10, s. 100. Polski przekład: Kiedy umiera gospodarz, nawet bydlatka płacza], przeł. A. Czcibor-Piotrowski, w: B. Hrabal, Taka piękna żałoba, Izabelin 1997, s. 129.

11. Žlutý ptak, w zbiorze Krasosmutnění, SsBH, t. 10, s. 167. Polski przekład: Żótty ptak, przeł. A. Czcibor-Piotrowski, w: B. Hrabal, Taka piękna żałoba, Izabelin 1997, s. 224.

12. Autícko. Balada, w zbiorze Kdo jsem, SsBH, t. 12, Praha 1995, s. 95 . Polski przekład: Auteczko. Ballada, przeł. J. Paczesniak, w: B. Hrabal, Auteczko, Kraków 2003*, s. 14-15.

13. Tř́nohý kůn̆ na dostihové dráze, w zbiorze Listopadový uragán, SsBH, t. 13, Praha 1995, s. 72. Polski przekład, Kon o trzech nogach na torze wyścigowym, przeł. A. Czcibor-Piotrowski, w: B. Hrabal, Listy do Kwiecieńki, Warszawa 2004, s. 80.

14. Cassius v emigraci, w zbiorze Ponorné ř́čky, SsBH, t. 13, s. 223. Polski przekład: Cassius na emigracji, przeł. A. Czcibor-Piotrowski, w: B. Hrabal, Listy do Kwiecieńki, Warszawa 2004, s. 270.

15. Písečný kocour w zbiorze Ponorné říčky, SsBH, t. 13, s. 233. Polski przekład: Płowe kocisko, przeł. A. Czcibor-Piotrowski, w: B. Hrabal, Listy do Kwiecieńki, Warszawa 2004, s. 283.

16. Kůn̆ truhlăre Bárty, w zbiorze Růžový kavalír, SsBH, t. 13, s. 343. Polski przekład: Koń stolarza Bárty, przeł. K. Kępka, w: B. Hrabal, Różowy kawaler, Izabelin 2005, s. 43.

17. Kočiči šibřinky aneb zpověd bez rozhřešení, w zbiorze Večernićčky pro Cassia, SsBH, t. 14, Praha 1996, s. 139. Polski przekład: Kocia maskarada, czyli spowiedź bez rozgrzeszenia, przeł. A. Czcibor-Piotrowski, w: B. Hrabal, Dobranocki dla Cassiusa, Izabelin 2004, s. 74.

18. A havran krák už nikdykrát, w zbiorze jak wyżej, s. 180. Polski przekład: Kruk zakrakat: „Nigdy już”], w: B. Hrabal, Dobranocki dla Cassiusa, Izabelin 2004, s. 133.

19. Zavražděný kohout, w zbiorze Balony mohou vzlétnout], SsBH, t. 14, s. 200. Polski przekład: Zabity kogut, przeł. K. Kępka-Falska i M. Falski, w: B. Hrabal, Balony mogq wzlecieć, Izabelin 2009, s. 12.

20. Ubili konícka ubili, w zbiorze Balony mohou vzlétnout], SsBH, t. 14, s. 222. Polski przekład Zabili konika, zabili, w: B. Hrabal, Balony moga wzlecieć, Izabelin 2009, s. 42.

21. Kot'ata a kocouři [Kocięta i kocury], w zbiorze Domácí úkoly (Úvahy a rozhowory) [Zadania domowe. Uwagi i rozmowy], SsBH, t. 15, Praha 1995, s. 101.

\footnotetext{
* Auteczko i Cassius to imiona ulubionych kotów Hrabala.
} 
22. Přes ty svoje kočky se stanu tak trochu nesmrtelným [Dzięki tym moim kotom stanę się trochę nieśmiertelny], w zbiorze Domácí úkoly z pilnosti [Nadobowiązkowe zadania domowe], SsBH, t. 15, s. 16.

\title{
Bibliografia
}

Baluch Jacek (1969), "Lewoboczek" $i$ "Pabitele”. Felieton filologiczny z dwoma podtytutami..., „Nurt", nr 8, s. 40-42.

Baratay Éric (2014), Zwierzęcy punkt widzenia. Inna wersja historii, przeł. P. Tarasewicz, Gdańsk: Wydawnictwo w Podwórku.

Czaja Dariusz (2009), Filozofowie i zwierzęta. Poeci i zwierzęta. Wypisy z ksiag użytecznych, „Konteksty. Polska Sztuka Ludowa”, nr 4, s. 10-26.

Czaja Dariusz (2009), Przefarbowany świat. Mitologie polowania, „Konteksty. Polska Sztuka Ludowa", nr 4, s. 110-125.

Eco Umberto (1999), Eugène Sue: il socialismo e la consolazione, w: U. Eco, Il superuomo di massa. Retorica e ideologia nel romanzo popolare, Milano: Bompiani.

Eco Umberto (2007), Eugeniusz Sue: socjalizm i pocieszenie, w: U. Eco, Superman w literaturze masowej. Powieść popularna między retoryka a ideologia, przeł. J. Ugniewska, Kraków: Znak.

Goszczyńska Joanna (2015), Zwierzęta w krainie Hrabala, w: W poszukiwaniu przerw w zabudowie. W stulecie urodzin Bohumila Hrabala, red. J. Goszczyńska, Warszawa: Wydział Polonistyki Uniwersytetu Warszawskiego, s. 163-175.

Pavel Ota (2015), Śmierć pięknych saren. Jak spotkałem się z rybami, przeł. A. Czcibor-Piotrowski, Warszawa: Czuły Barbarzyńca.

Serpell James (1999), W towarzystwie zwierząt. Analiza zwiazków ludzie-zwierzęta, przeł. A. Alichniewicz, A. Szczęsna, Warszawa: PIW.

\section{With Hrabal Among Animals}

\begin{abstract}
The article aims to interpret the so-called 'animal prose' by Bohumil Hrabal using some of the contemporary tools developed within animal studies, especially those that directly or indirectly address the broadly understood question of hunting. By 'animal prose' the author of this article understands these works by the Czech writer whose protagonists or narrative personae are wild, domesticated and breed animals, including the domestic and homing pigeons. All Hrabal's works show a discernible tension in the human protagonists, torn between the species guilt and the realization that a return to the natural state is a classic example of wishful thinking.
\end{abstract}

Keywords: animal studies, Czech literature, animals, hunting, nature 